\title{
Involvement of distinct PKC gene products in T cell functions
}

\section{Christa Pfeifhofer-Obermair, Nikolaus Thuille and Gottfried Baier*}

Division of Cell Genetics, Department of Pharmacology and Genetics, Medical University Innsbruck, Innsbruck, Tyrol, Austria

\section{Edited by:}

Noah Isakov, Ben-Gurion University of the Negev, Israel

\section{Reviewed by:}

Edward John Collins, The University of North Carolina at Chapel Hill, USA Jose Alberola-lla, Oklahoma Medical Research Foundation, USA

*Correspondence:

Gottfried Baier, Division of Cell Genetics, Department of

Pharmacology and Genetics, Medical University Innsbruck, Schoepfstr. 41 A-6020 Innsbruck, Tyrol, Austria.

e-mail: gottfried.baier@i-med.ac.at
It is well established that members of the protein kinase $C(P K C)$ family seem to have important roles in T cells. Focusing on the physiological and non-redundant PKC functions established in primary mouse T cells via germline gene-targeting approaches, our current knowledge defines two particularly critical PKC gene products, PKC $\theta$ and $P K C \alpha$, as the "flavor of PKC" in T cells that appear to have a positive role in signaling pathways that are necessary for full antigen receptor-mediated $T$ cell activation ex vivo and $T$ cell-mediated immunity in vivo. Consistently, in spite of the current dogma that PKC $\theta$ inhibition might be sufficient to achieve complete immunosuppressive effects, more recent results have indicated that the pharmacological inhibition of $\mathrm{PKC} \theta$, and additionally, at least $\mathrm{PKC} \alpha$, appears to be needed to provide a successful approach for the prevention of allograft rejection and treatment of autoimmune diseases.

Keywords: T cell regulation, protein kinases, PKC isotypes, immune disease therapy

\section{INTRODUCTION}

Members of the protein kinase C (PKC) family belong to the serine/threonine protein kinase subfamily, which plays an important role in the regulation of a variety of cell functions (Figure 2). The PKC family was originally discovered by Nishizuka and colleagues in 1977 (Takai et al., 1977) and consists of nine isotypes that are expressed in a wide range of cell types and tissues (Figure 1). The reasons for the heterogeneity of $\mathrm{PKC}$ isotypes are not yet fully understood. T lymphocytes, for example, express up to eight different species of PKC isotypes (Table 1), which makes it difficult to determine the specific cellular functions of these individual enzymes. The expression of more than a single PKC isotype in a given cell could suggest functional redundancy and/or specialization. Table 1 summarizes the overall lymphoid expression patterns and $\mathrm{T}$ cell phenotypes of knockout $\mathrm{T}$ cells and the different PKC isotypes encoded in the human genome.

\section{ROLE OF PKC $\theta$ IN IMMUNE CELL BIOLOGY}

The main function of mature $\mathrm{T}$ cells is to recognize and respond to foreign antigens. This process involves the activation, adhesion, and differentiation of the resting cell into an effector lymphoblast that actively secretes immunoregulatory lymphokines or displays targeted cytotoxicity, ultimately leading to the recruitment of other cell types and initiation of an effective immune response. $\mathrm{T}$ cell activation is triggered by the ability of the $\mathrm{T}$ cell receptor (TCR) to recognize a peptide antigen, which is bound to major histocompatibility complex class I (MHCI) or class II (MHCII). T cells then begin to divide and differentiate on the basis of the processed antigen. The effector cell $\mathrm{CD}_{4}^{+}$ $\mathrm{T}$ helper cell subset (including $\mathrm{T}_{\mathrm{H}} 1, \mathrm{~T}_{\mathrm{H}} 2$, and $\mathrm{T}_{\mathrm{H}} 17$ cells) performs effector functions that are necessary to clear the pathogen. $\mathrm{T}_{\mathrm{H}} 1 \mathrm{CD}^{+} \mathrm{T}$ cells produce IFN- $\gamma$ and IL- 2 and promote cellmediated immunity. $\mathrm{T}_{\mathrm{H}} 2 \mathrm{CD}^{+}{ }^{+} \mathrm{T}$ cells produce IL-4, IL-5, IL-6, IL-10, and IL-13 and lead to the activation of the humoral immune system. $\mathrm{T}_{\mathrm{H}} 17 \mathrm{CD} 4^{+} \mathrm{T}$ cells produce IL-17, IL-21, and IL-22 and play roles in the defense against extracellular bacteria and fungi.

\section{INVOLVEMENT OF PKC $\theta$ IN THE IMMUNOLOGICAL SYNAPSE}

After cell-cell contact between a T cell and an APC, this contact is stabilized during the initiation of an immune response by interaction of the $\beta 2$-integrin LFA- 1 with its counterligand ICAM-1 (Mazerolles et al., 1988; Dustin and Springer, 1989; Penninger and Crabtree, 1999). LFA-1 avidity is controlled by inside-out signaling via the control of integrin conformation and surface distribution (Lub et al., 1995; Carman and Springer, 2003; Dustin et al., 2004). One important inside-out signaling molecule that controls cell adhesion is the small GTPase Rap1 (Katagiri et al., 2002; Shimonaka et al., 2003). Rap1A-deficient T cells show impaired LFA-1 clustering and adhesion after CD3 stimulation (Duchniewicz et al., 2006). Letschka et al. (2008) found a role of a PKCO/RapGEF2 complex in regulating LFA-1 avidity in $\mathrm{T}$ cells. These authors showed that after $\mathrm{T}$ cell activation, PKC $\theta$ phosphorylates RapGEF2 at Ser960, which regulates Rap1 activation and LFA-1 adhesiveness to ICAM-1. In agreement, this study showed that in OT-II TCR-transgenic CD $4^{+} \mathrm{T}$ cells, LFA-1 clustering after antigen activation was impaired in $\mathrm{PKC} \theta-$ deficient $\mathrm{CD}^{+}{ }^{+} \mathrm{T}$ cells (Letschka et al., 2008). According to their study, PKC $\theta$ seems to positively regulate the adhesive capacity of T lymphocytes.

When a stable contact between a T cell and an APC is formed, the $\mathrm{T}$ cell co-stimulatory receptor $\mathrm{CD} 28$ is activated by binding to its cell ligands CD80 or CD86. Subsequently, the immunological synapse is generated at the contact area between the $\mathrm{T}$ cell and the APC (Rao et al., 1999). Part of the immunological synapse is the supramolecular activation complex (SMAC), which is characterized by different signaling proteins, such as LCK (SRC family tyrosine kinase), LFA-1 (lymphocyte function-associated 


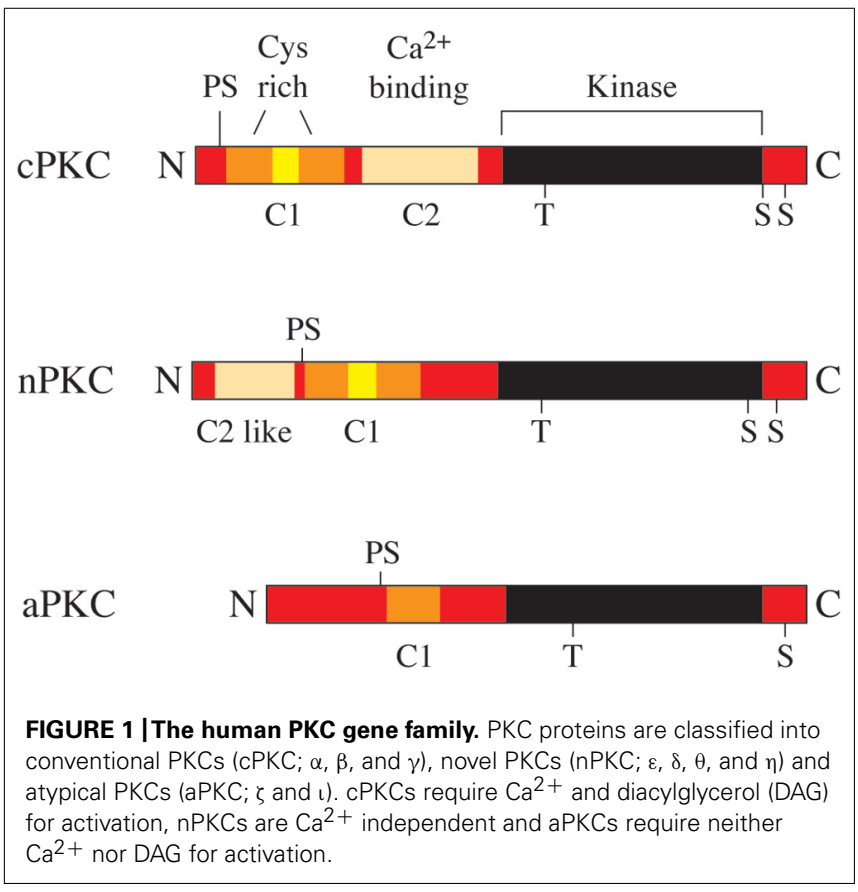

antigen 1), and CD45 (Freiberg et al., 2002). Effective T cell stimulation is characterized by the recruitment of $\mathrm{PKC} \theta$ to the SMAC (Schaefer et al., 2004), at which it is phosphorylated by LCK at Tyr-90 (Liu et al., 2000). A physical interaction of PKC $\theta$ with the cytoplasmatic tail of CD28 has been shown to be essential in this recruitment mechanism (Kong et al., 2011). Subsequently, PKC $\theta$ is phosphorylated at different sites (Bauer et al., 2001; Bi et al., 2001; Liu et al., 2002; Freeley et al., 2005; Lee et al., 2005) and autophosphorylated at Thr-219 (Thuille et al., 2005). Recently, Chuang et al. (2011) identified the MAP4K3 GCK-like kinase (GLK) as a kinase that directly phosphorylates $\mathrm{PKC} \theta$ at Thr-538 which is essential to activation of NF- $\kappa \mathrm{B}$ in T cells. Phosphorylation is important to retain $\mathrm{PKC} \theta$ in the immunological synapse, in which one of its functions seems to be the regulation of the immunological synapse itself. Through the live imaging of components of the immunological synapse, the synapse has been shown to be dynamic in wild-type mice but more stable in PKC $\theta$-knockout mice, which influences the strength, duration and location of signals (Dustin, 2008).

\section{RECRUITMENT AND ACTIVATION OF SIGNALING MOLECULES}

Another important role of PKC $\theta$ is to recruit and activate signaling molecules, such as phospholipase C (PLC), IL2-inducible T cell kinase (ITK), TEC, phospholipase C $\gamma 1$ (PLC $\gamma 1$ ), and SPAK (a MAPKKK that ultimately activates AP1) to the immunological synapse. PKC $\theta$ was identified to play a critical role in the $\mathrm{NF}-\kappa \mathrm{B}$ and $\mathrm{Ca}^{2+} / \mathrm{NFAT}$ pathways to activate the IL-2 promoter. Antigen binding to the TCR leads to an increase in intracellular $\mathrm{Ca}^{2+}$, which activates calcineurin. Calcineurin dephosphorylates NFAT and leads to its nuclear import. Subsequently, NFAT forms complexes with the AP-1 protein transcription factor family and regulates the expression of IL-2 by binding to its promoter. PKC $\theta$-knockout $\mathrm{T}$ cells were first described by

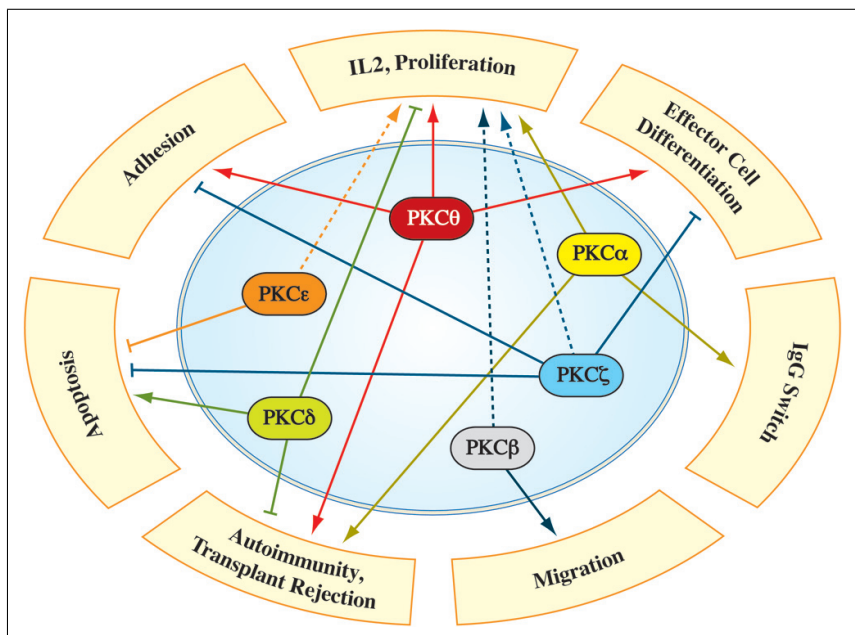

FIGURE 2 | Involvement of individual PKC family members in different aspects of T cell biology. Numerous studies identified PKC isotype-selective functions in signaling pathways, necessary for full T cell activation, differentiation and robust immune responses in vivo (for details see text). The dashed line depicts PKC functions which were characterized primarily via overexpression/knockdown studies in immortalized cell lines, while a validation in a more physiological system is pending.

Sun et al. (2000). They generated PKC $\theta$-knockout mice by replacing the exon encoding the ATP-binding site of the kinase domain with the neomycin resistance gene. In their study they found strongly reduced proliferation of $\mathrm{PKC} \theta^{-/-} \mathrm{CD}^{+} \mathrm{T}$ lymphocytes accompanied by a reduced secretion of IL-2. Suitably they could show that TCR-initiated NF- $\kappa$ B activation was absent from $\mathrm{PKC}^{-/-} \mathrm{CD}^{+} \mathrm{T}$ lymphocytes but was normal in thymocytes indicating that PKC $\theta$ is essential for TCR-mediated T cell activation (Sun et al., 2000).

Pfeifhofer et al. (2003) generated a conditional PKC $\theta$-knockout mouse by using Cre-mediated recombination where the complete coding sequences of exons 3 and 4 are deleted, followed by a frame shift mutation between exons 2 and 5. Additionally to the results Sun et al. (2000) observed, they saw that a deficiency of PKC $\theta$ abrogates NFAT transactivation after CD3/CD28 stimulation. In addition, decreased intracellular $\mathrm{Ca}^{2+}$ flux was observed (Pfeifhofer et al., 2003).

To induce and maintain the complete IL-2-producing capacity of a T cell after TCR stimulation and activation of CD28, the RING (really interesting new gene)-type E3 ubiquitin ligase Cbl-b must be inhibited. Cbl-b restricts activation of the TCR by inhibiting the activation of PI3K (phosphoinositide-3-kinase; Fang and Liu, 2001) and PLC $\gamma 1$ (Heissmeyer et al., 2004; Jeon et al., 2004), and it promotes the antigen-induced downregulation of the TCR (Naramura et al., 2002). In response to the stimulation of CD28, Cbl-b is ubiquitinylated and proteasomally degraded. Gruber et al. (2009a) showed that PKC $\theta$ directly regulates the ubiquitinylation and degradation of Cbl-b. After co-stimulation of the TCR and CD28, Cbl-b was degraded in wild-type $\mathrm{CD}^{+} \mathrm{T}$ cells but not $\mathrm{PKC} \theta$-deficient $\mathrm{CD}^{+} \mathrm{T}$ cells, and the ubiquitinylation of Cbl-b was strongly decreased after treatment with an inhibitor of PKC $\theta$ (Gruber et al., 2009a). 
Table 1 | Lymphoid expression pattern and immune cell phenotypes of PKC isotype knockout mice.

\begin{tabular}{|c|c|c|c|}
\hline Gene loci & Tissue expression & Knockout mouse immune phenotype & Reference \\
\hline \multicolumn{4}{|c|}{ Conventional PKCs } \\
\hline$\alpha$ & Ubiquitous, high in T cells & Reduced proliferation, reduced IFN $\gamma$ production, defective IgG switching & Pfeifhofer etal. (2006) \\
\hline$\beta$ & Ubiquitous, high in B cells & Neutrophil-, B-, mast cell defect & Leitges etal. (1996), \\
\hline & & & Nechushtan et al. (2000) \\
\hline$\gamma$ & Brain & ND & \\
\hline \multicolumn{4}{|c|}{ Novel PKCs } \\
\hline \multirow[t]{2}{*}{$\delta$} & Ubiquitous, high in T cells & Enhanced IL-2 secretion, enhanced proliferation, proapoptotic & Gruber etal. (2005), \\
\hline & & & Lutz-Nicoladoni et al. (2005) \\
\hline \multirow[t]{2}{*}{$\varepsilon$} & Ubiquitous, high in T cells & Macrophage defect, defective bacterial clearance, influence on the & Castrillo etal. (2001), \\
\hline & & nervous system & Kumar et al. (2002) \\
\hline \multirow[t]{3}{*}{$\eta$} & Ubiquitous, high in T cells & Impairment of epithelial regeneration in wound healing, increased & Chida et al. (2003), \\
\hline & & susceptibility to tumor formation in skin carcinogenesis, defective & Fu et al. (2011) \\
\hline & & homeostatic proliferation & \\
\hline \multirow[t]{4}{*}{$\theta$} & T cells, platelets, monocytes & Reduced proliferation, reduced IL-2 production, abrogated $A P-1, N F-\kappa B$, & Sun etal. (2000), \\
\hline & & and NFAT transactivation, impaired EAE development, impaired $\mathrm{T}_{\mathrm{H}} 2$ & Pfeifhofer etal. (2003), \\
\hline & & immunity against $N$. brasiliensis & Marsland et al. (2004), \\
\hline & & & Salek-Ardakani et al. $(2004,2005)$ \\
\hline \multicolumn{4}{|c|}{ Atypical PKCs } \\
\hline$\zeta$ & Ubiquitous & Impaired $\mathrm{T}_{\mathrm{H}} 2$ cytokine secretion response & Martin et al. (2005) \\
\hline$\iota$ & Ubiquitous & Lethal phenotype & \\
\hline
\end{tabular}

\section{IN VIVO IMMUNE RESPONSES}

During $\mathrm{T}$ cell development, thymocytes undergo a twofold selection process. During positive selection, $\mathrm{CD} 4^{+} \mathrm{CD} 8^{+}$doublepositive thymocytes bearing TCRs with low or moderate affinity to $\mathrm{MHC} /$ antigen complexes expressed on epithelial cells receive a survival signal. During negative selection, the high-affinity interaction of TCRs with self-MHC/self-peptide complexes selects the thymocytes for apoptosis. Selected thymocytes downregulate CD4 or CD8 and leave the thymus as fully mature lymphocytes. To address the question of whether PKC $\theta$ is involved in positive selection, Morley et al. (2008) analyzed MHCII-restricted TCR-

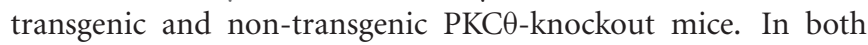
mouse models, they found a severe defect in thymocyte positive selection (Morley et al., 2008). In agreement with these results, Gruber etal. (2010) also found a crucial role for PKC $\theta$ in the positive selection of thymocytes in a pathway leading to the activation of ERK, NFAT, and NF- $\mathrm{KB}$ by analyzing MHCI-restricted TCR-transgenic mice and non-transgenic PKC $\theta$-knockout mice. When a naive $\mathrm{CD}^{+} \mathrm{T}$ cell is activated, it differentiates into the effector subsets $\mathrm{T}_{\mathrm{H}} 1, \mathrm{~T}_{\mathrm{H}} 2$, or $\mathrm{T}_{\mathrm{H}} 17$. An imbalance of this differentiation leads to autoimmunity and hypersensitivity. Several studies showed that PKC $\theta$ is important in the regulation of the $\mathrm{T}_{\mathrm{H}}$ 2-mediated immune response (Marsland et al., 2004; Salek-Ardakani et al., 2004, 2005; Tan et al., 2006). After infection with Nippostrongylus brasiliensis, $\mathrm{T}_{\mathrm{H}} 2$ cell immune responses were severely impaired in $\mathrm{PKC}^{-/-}$mice. Consistent with these results, another in vivo study showed that PKC $\theta$ appears to be involved in lung inflammation responses, which are controlled by $\mathrm{T}_{\mathrm{H}} 2$ cells (Marsland et al., 2004; Salek-Ardakani et al., 2004). PKC $\theta^{-/-}$mice develop drastically reduced pulmonary hypersensitivity responses to inhaled allergens, such as lung inflammation, eosinophil infiltration, and immunoglobulin E production.

To address the question of whether PKC $\theta$ is involved in protection against bacterial infections, Sakowicz-Burkiewicz et al. (2008) infected mice with Listeria monocytogenes (LM) and found that $\mathrm{PKC} \theta$ is responsible for normal $\mathrm{LM}$-specific $\mathrm{T}$ cell responses. Fauconnier et al. (2011) studied the role of PKC $\theta$ after the infection of mice with Plasmodium falciparum. They found that PKC $\theta-$ deficient mice are resistant to the development of cerebral malaria, and the recruitment and activation of $\mathrm{CD}^{+} \mathrm{T}$ cells in the brains of the resistant mice were reduced. To study the function of PKC $\theta$ in a chronic persisting infection model, Nishanth et al. (2010) infected mice with Toxoplasma gondii. PKCO-deficient mice suffered from encephalitis and showed insufficient parasite control. T. gondiispecific $\mathrm{CD}^{+}$and $\mathrm{CD} 8^{+} \mathrm{T}$ cells were significantly reduced in the spleens and brains of infected PKC $\theta$-deficient mice, indicating that $\mathrm{PKC} \theta$ is important for intracerebral parasite control (Nishanth et al., 2010).

Tan et al. (2006) and Salek-Ardakani et al. $(2004,2005)$ showed that PKC $\theta$ is also important for full development of experimental autoimmune encephalomyelitis (EAE), a multiple sclerosis-like autoimmune disease that is $\mathrm{T}_{\mathrm{H}} 17$ dependent. $\mathrm{PKC} \theta^{-/-}$mice failed to develop EAE after injection with myelin oligodendrocyte 
glycoprotein (MOG). In addition, $\mathrm{T}_{\mathrm{H}} 17$ cells produced less IL-17 and failed to infiltrate the CNS.

Recently, Kwon et al. (2012) showed that $\mathrm{PKC} \theta^{-/-}$mice had lower levels of Stat3, a transcription factor required for $\mathrm{T}_{\mathrm{H}} 17$ differentiation, whereas the activation of Stat 4 and Stat6, which are important for $\mathrm{T}_{\mathrm{H}} 1$ and $\mathrm{T}_{\mathrm{H}} 2$ differentiation was normal. Using a luciferase reporter gene driven by the Stat 3 promoter they showed that PKC $\theta$ stimulates Stat 3 transcription via the NF- $\kappa$ B and AP1 pathway, resulting in the stimulation of $\mathrm{T}_{\mathrm{H}} 17$ differentiation (Kwon et al., 2012).

In striking contrast, $\mathrm{PKC} \theta^{-/-}$mice showed normal $\mathrm{T}_{\mathrm{H}} 1$ responses after infection with Leishmania major (Marsland et al., 2004), suggesting a lineage-specific function of PKC $\theta$.

Garaude etal. (2008) found an impaired anti-leukemic response in $\mathrm{PKC} \theta$-deficient mice. These authors induced leukemia with Moloney-murine leukemia virus and found a higher disease incidence and a more rapid disease onset in PKC $\theta$-knockout mice. Additionally, the intravenous injection of EL4 cells induced tumors earlier in $\mathrm{PKC} \theta^{-/-}$mice.

To avoid an uncontrolled immune response, the maintenance of the balance between immune tolerance to self-antigens and antitumor responses and the regulation of the suppression of effector $\mathrm{T}$ cells is mediated by regulatory $\mathrm{T}$ cells $\left(\mathrm{T}_{\text {reg }}\right.$ cells; Sakaguchi et al., 2008). $\mathrm{T}_{\text {reg }}$ cells are produced in the thymus $\left(\mathrm{nT}_{\text {reg }}\right)$ or from naive effector $\mathrm{T}$ cells ( $\mathrm{iT}_{\text {reg }}$ ), and both types of $\mathrm{T}_{\text {reg }}$ cells express the transcription factor FoxP3, whereas $\mathrm{nT}_{\text {reg }}$ cells also express Helios (Zheng and Rudensky, 2007; Thornton et al., 2010). T reg cells are able to suppress the function of $\mathrm{CD} 4^{+}$and $\mathrm{CD} 8^{+} \mathrm{T}$ cells, dendritic cells (DCs), NK cells, and B cells (Gupta et al., 2008b; Shevach, 2009). A deficiency of $\mathrm{T}_{\text {reg }}$ cells leads to multi-organ inflammatory diseases in mice (Sakaguchi et al., 2008). Gupta et al. (2008a) found a strongly reduced number of $\mathrm{T}_{\text {reg }}$ cells in PKC $\theta$ knockout mice, but these cells were as potent as wild-type $\mathrm{T}_{\text {reg }}$ cells in inhibiting effector T cell activation, indicating that PKC $\theta$ was not required for $\mathrm{T}_{\text {reg }}$ cell-mediated inhibitory functions. However, Zanin-Zhorov et al. (2011) found that PKC $\theta$ was sequestered away from the $\mathrm{T}_{\text {reg }}$ immunological synapse with confocal imaging, and using a colitis mouse model and a poorly described $\mathrm{PKC} \theta$ inhibitor, they postulated a $\mathrm{PKC} \theta$-mediated negative feedback loop that enhances the activity of human $\mathrm{T}_{\text {reg }}$ cells. A very recent publication by Ma et al. (2012) suggested that the differentiation of $\mathrm{iT}_{\text {reg }}$ cells is inhibited by $\mathrm{PKC} \theta$-mediated signals via the AKT-Foxo1/3A pathway.

\section{ROLE OF OTHER PKCs IN IMMUNE CELL BIOLOGY PKC $\delta$}

PKC $\delta$ is an isozyme belonging to a novel subclass of the serine/threonine PKC family and is expressed in most tissue and cell types. The kinase catalytic activity of PKC $\delta$ is mainly affected by trans- and autophosphorylation at conserved Ser/Thr sites in the catalytic domain (activation loop, turn motif, and hydrophobic motif), by tyrosine phosphorylation (by Src family kinases in the context of oxidative stress and DNA damage; Lu etal., 2007; Lomonaco et al., 2008) and by caspase-mediated proteolysis (during apoptosis; Kikkawa et al., 2002). Generally, upon stimulation, PKC $\delta$ translocates from the cytosol or nucleus to membrane/cytoskeletal compartments, enabling the phosphorylation of many target proteins and leading to the activation of several signal transduction pathways. It has also been shown that PKC $\delta$ can shuttle to mitochondria (Li et al., 1999; Majumder etal., 2001). PKC $\delta$ negatively affects a wide variety of cellular functions by inhibiting cellular growth and proliferation and promoting cell death, but it has also been shown to contribute to mitogenesis (Watanabe et al., 1992; Nakagawa et al., 2005; Santiago-Walker etal., 2005), migration (Jackson etal., 2005), differentiation (Cerda et al., 2001; Yang et al., 2006; Zhang et al., 2008), and tumor progression. Different studies have revealed a role for PKC $\delta$ in the initiation, progression, and maintenance of inflammatory processes by affecting NF- $\mathrm{B}$ transactivation (Satoh et al., 2004; Hsieh et al., 2007).

Additionally, a pro-apoptotic role for PKC $\delta$ has been described in T cells. The subcellular localization of PKC $\delta$ in human T cells during apoptotic induction by cytokine deprivation and Fas ligation and during the prevention of apoptosis by IFN $\beta$ addition was analyzed by Scheel-Toellner et al. (1999). The addition of INF $\beta$ to T cells in a pro-apoptotic environment led to a rapid retranslocation of PKC $\delta$ from the nucleus and inhibited the caspase3-mediated proteolytic activation of PKC $\delta$ (Scheel-Toellner et al., 1999). An essential role for PKC $\delta$ in the apoptotic induction of mouse thymocytes was addressed in a study by Lutz-Nicoladoni et al. (2005). Thymocytes from a large panel of PKC-knockout mice were forced to undergo apoptosis in vitro via treatment with different apoptotic inducers (PDBu, dexamethasone, FasL, staurosporine, or etoposide), and the selective involvement of PKC isotypes in this process was assessed. PKC $\delta$-deficient primary mouse double-positive thymocytes were protected from apoptotic induction, indicating a clear pro-apoptotic role of PKC $\delta$ (Lutz-Nicoladoni et al., 2005). Gruber et al. (2005) investigated the proliferative response and IL-2 cytokine secretion of $\mathrm{PKC} \delta$-deficient $\mathrm{CD}^{+}{ }^{+} \mathrm{T}$ cells versus control cells in vitro via allogenic MHC stimulation and in vivo via injection of anti-CD3 antibodies. The significantly enhanced proliferation and IL-2 cytokine production of mature $\mathrm{T}$ cells and the increased blood plasma IL-2 levels in PKC $\delta$-null mice led to the assumption that $\mathrm{PKC} \delta$ acts as a negative regulator of $\mathrm{T}$ cell activation responses (Gruber et al., 2005).

An involvement of PKC $\delta$ in lytic granule exocytosis of CD8CTLs (cytotoxic T lymphocytes) was shown by Ma et al. (2007, 2008). The combined use of pharmacological inhibitors and mice with targeted gene deletions allowed these authors to demonstrate that PKC $\delta$ is selectively required for lytic granule movement in response to TCR engagement on $\mathrm{CD}^{+}$CTLs but is dispensable for activation, cytokine production, and the expression of cytolytic molecules in response to TCR stimulation. In a followup study, the authors showed via a time-lapse analysis of living $\mathrm{CD}^{+}$CTLs that PKC $\delta$ localizes to secretory lysosomes and accumulates at the immunological synapse during target killing (Ma et al., 2007, 2008).

A correlation between impaired $\mathrm{PKC} \delta$ activation/ phosphorylation and the development of idiopathic and hydralazine-induced lupus was postulated by Gorelik et al. (2007). PMA-stimulated $\mathrm{CD}^{+}{ }^{+} \mathrm{T}$ cells from patients with lupus showed an impaired PKC $\delta$ activity state compared with $\mathrm{CD} 4^{+} \mathrm{T}$ cells from healthy donors. This defect was responsible for decreased ERK signaling and led 
to increased CD70 expression due to insufficient demethylation of the CD70 promoter (Gorelik et al., 2007).

The expression level and activity state of $\mathrm{PKC} \delta$ and $\mathrm{PKC} \zeta$ was investigated in amyloid $\beta 1-42(\mathrm{~A} \beta 1-42)$-reactive $\mathrm{T}$ cell populations in Alzheimer disease (AD) patients in comparison to healthy individuals. This study clearly showed the increased expression and activation of PKC $\delta$ in $A \beta$-stimulated peripheral T cells from early AD patients, whereas the same treatment induced two distinct (p)PKC $\delta$ and (p)PKC $\zeta$ T cell subpopulations in severe AD patients (Miscia et al., 2009).

\section{PKC ع}

$\mathrm{PKC} \varepsilon$ was first discovered among the novel PKC isotypes and is expressed at high levels in neuronal, hormonal, and immune cells. Essential roles for PKC $\varepsilon$ have been established in numerous cellular functions, including proliferation, differentiation, gene expression, muscle contraction, transport, tumorigenesis, exocytosis, and endocytosis. In addition to the classical activation by auto- and trans-phosphorylation at conserved sites in the catalytic domain, $\mathrm{PKC} \varepsilon$ is activated by several different second messengers, including diacylglycerol (DAG), phosphatidylinositol-3,4,5triphosphate, and fatty acids. PKC $\varepsilon$ is targeted to specific cellular compartments depending on the interaction of second messengers with its C1 domain (DAG and tridecanoic acids evoke a plasma membrane and/or cytoskeleton translocation, whereas arachidonic and linoleic acids lead to recruitment to Golgi networks) and via crosstalk with adaptor proteins (i.e., Rack1 and $\beta$-Cop). An association of $\mathrm{PKC} \varepsilon$ (via its actin-binding motif) with actin filaments in response to phosphatidylserine-independent stimulation has been reported (Akita, 2002).

In $\mathrm{T}$ cells, numerous studies have directly shown a positive role of $\mathrm{PKC \varepsilon}$ in the regulation of $\mathrm{NF}-\kappa \mathrm{B} / \mathrm{NFAT} / \mathrm{AP} 1$ pathways leading to IL-2 upregulation; the activation-dependent translocation of PKC $\varepsilon$ from the cytosol to the membrane compartment in TCR/CD3- or PMA-stimulated human PBLs has been reported previously (Keenan etal., 1997). The neutralization of PKC $\varepsilon$ in this cell type via the introduction of antagonistic antibodies led to a downregulation of IL-2 synthesis (Szamel etal., 1998). Jurkat T cells expressing a constitutively active PKCE mutant showed increased AP1 and NFAT1 transactivation (Genot et al., 1995). An inhibitory effect of eicosapentaenoic acid (EPA) and docosahexaenoic acid (DHA) in the plasma membrane translocation of $\mathrm{PKC \varepsilon}$ (and $\mathrm{PKC} \alpha$ ), NF- $\mathrm{B}$ nuclear translocation, and IL-2 transcription in PMA-stimulated Jurkat T cells has been described (Denis et al., 2005). A pivotal role for PKCE in thrombin-mediated ERK1/2 activation in Jurkat cells has been shown by Maulon etal. (2001). The poor ability of neonatal $\mathrm{T}$ cells to produce lymphokines was linked to a lower PKCE (and PKC $\beta, P K C \theta$, and $\mathrm{PKC} \zeta$ ) expression level in this cell type, which is correlated with an activation defect of MAPK pathways (Hii et al., 2003).

Interestingly, Gruber et al. (2005) reported that mice carrying a homozygous disruption of the PKCE locus showed unaltered $\mathrm{T}$ cell development and maturation; in addition, mature primary $\mathrm{CD}^{+} \mathrm{T}$ cells isolated from $\mathrm{PKC} \varepsilon^{-/-}$mice showed normal proliferation, IL-2 secretion responses, and NF- $\mathrm{B}$ transactivation upon CD3/CD28 stimulation or allogeneic MHC presentation, suggesting that $\mathrm{PKC} \varepsilon$ loss of function is compensated for by other members of the PKC family. In contrast to the described redundant function of $\mathrm{PKC} \varepsilon$ in mouse $\mathrm{T}$ cell proliferation, a role of the $\mathrm{PKC \varepsilon}$ isotype in the regulation of human $\mathrm{CD}_{4}^{+}$ $\mathrm{T}$ cell proliferation and sensitivity to TGF $\beta 1$ has been shown by Mirandola etal. (2011). PKCE silencing by siRNA led to decreased IL-2 receptor chain expression and proliferation and reduced $\mathrm{NF}-\kappa \mathrm{B} 1$ and $\mathrm{NF}-\kappa \mathrm{B} 2$ gene expression upon $\mathrm{CD} 3 / \mathrm{CD} 28$ stimulation, whereas the inhibitory effects of TGF $\beta 1$ were potentiated by $\mathrm{PKC} \varepsilon$ downregulation. In addition, a possible connection between increased $\mathrm{PKC} \varepsilon$ expression levels in $\mathrm{CD}_{4}^{+}$ $\mathrm{T}$ cells from Hashimoto thyroiditis patients and the molecular pathophysiology of this autoimmune disease was postulated (Mirandola et al., 2011).

Some studies have identified an anti-apoptotic role for PKC Jurkat $\mathrm{T}$ cells were rescued from Fas-mediated apoptosis by PKC $\varepsilon$ via the p90Rsk-dependent phosphorylation and inactivation of BAD (Bertolotto et al., 2000). The basis for the deletion of autoreactive thymocytes during negative selection was previously addressed (Simon et al., 2000); a lack of the constitutive expression of $\mathrm{PKC} \varepsilon$ in antigen-stimulated $\mathrm{CD} 4^{+} / \mathrm{CD} 8^{+}$thymocytes (in comparison to mature T cells) leading to an inhibition of NF- $\mathrm{B}$ activity and increased cell death was postulated as a probable cause.

A positive involvement of $\mathrm{PKC} \varepsilon$ in the recovery of downregulated sphingosine-1-phosphate receptor 1 (S1PR1) in primary mouse $\mathrm{CD}^{+} \mathrm{T}$ cells was investigated (Graeler et al., 2003) in $\mathrm{PKC} \varepsilon$-null mice and with $\mathrm{PKC} \varepsilon$-selective inhibitors.

Quann et al. (2011) established a new redundant role for PKCE and PKC $\eta$ in T cell polarity; the photoactivation of TCR induced a rapid accumulation of both PKC isotypes in a broader domain of the plasma membrane, in which they were required to promote the recruitment of $\mathrm{PKC} \theta$ to the center of the immunological synapse and subsequent microtubule-organizing center (MTOC) reorientation.

\section{$\operatorname{PKC} \zeta$}

PKC $\zeta$ is a calcium- and diacylglycerol-independent serine/ threonine protein kinase that belongs to the atypical subfamily of PKC isoforms and displays strong homology (more than $70 \%$ ) to $\mathrm{PKCl} / \lambda$. It is ubiquitously expressed but is more highly expressed in the lung, brain, and testis. PKC $\zeta$ contains a PB1 domain in the N-terminus that recognizes OPCA (OPR/PC/AID) motifs of other proteins, such as the scaffold proteins PAR-6 and ZIP/p62 and the kinase MEK5. PKC $\zeta$ activity is regulated by PDK1 transphosphorylation of the catalytic domain activation loop, autophosphorylation, and important lipid components, such as phosphatidylinositols, phosphatidic acid, arachidonic acid, PIP3, and ceramide. Prostate apoptosis response-4 (Par-4) and partitioning defective gene-3 (PAR-3) have been reported to inhibit $\mathrm{PKC} \zeta$ activity through a specific protein-protein interaction. $\mathrm{PKC} \zeta$ has been shown to be involved in the regulation of several critical pathways for cell survival, proliferation, differentiation, and cell polarity, thereby affecting the NF-кB and MAPK pathways. A special role in modulating translation via the p70S6 kinase signaling cascade has also been described by numerous studies (Hirai and Chida, 2003). Recently, a link between PKC $\zeta$ activity 
and TGF $\beta$ receptor trafficking and degradation has been shown (Gunaratne et al., 2012).

The activation of the PKC $\zeta$ isotype has been shown to be an important step in the IL-2-mediated proliferation of T cells and in maintaining the integrity of the actin cytoskeletal structure (Gomez et al., 1995). Furthermore, an association between $\mathrm{PKC} \zeta$ and PI3K has been reported to be necessary for the phosphorylation/activation of PI3K in IL-2-stimulated TS1- $\alpha / \beta$ mouse T cells (Gomez etal., 1996). Through the transient overexpression of wild-type or a dominant-negative mutant of $\mathrm{PKC} \zeta$ in Jurkat T cells, a previous study (San-Antonio etal., 2002) observed that PKC $\zeta$ can phosphorylate NFAT and regulate its activation status. Additionally, an involvement of both $\mathrm{PKC} \zeta$ and $\mathrm{PI} 3 \mathrm{~K}$ in $\mathrm{NF}-\kappa \mathrm{B} / \mathrm{c}-$ Rel transactivation regulation in $\mathrm{TNF} \alpha-$ stimulated Jurkat T cells was postulated (Martin et al., 2001). A previous study (Sanchez-Valdepenas et al., 2007) addressed the effect of TCR/CD28 co-stimulation on the inducible phosphorylation/transactivation of the NF- $\kappa$ B members p65/RelA and c-Rel. Cot kinase, $\mathrm{PKC} \zeta$, and NF- $\kappa \mathrm{B}$-inducible kinase (NIK) seemed to be involved in potentiating $\mathrm{c}$-Rel transactivation activity through the phosphorylation of a restricted set of Ser residues, whereas NIK seemed to be unnecessary for the activation of p65. Additionally, Gruber et al. (2008) found a physical and functional interaction between $\mathrm{PKC} \zeta$ and the novel PKC $\theta$ isotype in the NF- $\kappa \mathrm{B}$ activation of Jurkat T cells. A stimulation-dependent colocalization of the $\mathrm{PKC} \zeta / \mathrm{l}-\mathrm{PKC} \theta$ complex to lipid rafts was monitored via confocal microscopy. However, peripheral $\mathrm{CD}^{+} \mathrm{T}$ cells isolated from the spleen and lymph nodes of $\mathrm{PKC} \zeta$-deficient mice showed normal proliferation and IL-2 cytokine responses to CD3/CD28 activation, indicating a possible functional redundancy with $\mathrm{PKCl} / \lambda$, the closest structural relative (Gruber et al., 2008).

A critical role for PKC $\zeta$ in IL-4 signaling and $\mathrm{T}_{\mathrm{H}} 2$ differentiation in vitro and in vivo has been reported (Martin et al., 2005). PKC $\zeta$-deficient $C D 4^{+}$T cells showed an impaired secretion of $\mathrm{T}_{\mathrm{H}} 2$ cytokines and a defective Stat6/Jak1 pathway. Moreover, $\mathrm{PKC} \zeta^{-/-}$ mice were protected from ovalbumin-induced $\mathrm{T}_{\mathrm{H}} 2$-driven allergic airway disease in an asthma model.

A protective role for $\mathrm{PKC} \zeta$ against FasL-induced apoptosis was previously described (Leroy et al., 2005); PKC $\zeta$ interfered with FADD recruitment to the death-inducing signaling complex (DISC) and subsequent caspase- 8 processing.

$\mathrm{PKC} \zeta$ has been shown to act in combination with nitric oxide synthase (NOS) in the regulation of thyroid hormone (TH)mediated $\mathrm{T}$ cell proliferation (Barreiro Arcos et al., 2006); TH treatment increased atypical PKC $\zeta$ expression and NOS activity, whereas $\mathrm{PKC} \zeta$ inhibition abrogated the basal and $\mathrm{TH}$-induced activation of NOS.

A role for PKC $\zeta$ in the biological processes of adhesion and cell motility has been described by several studies. The mechanism of the CD4-triggered regulation of LFA-1-mediated adhesion was investigated (Trucy et al., 2006). CD4 binding increased the activity of both PDK1 and PKC $\zeta$, and both kinases were necessary for the downregulation of LFA-1-dependent adhesion in the A201-CD4 ${ }^{+} \mathrm{T}$ cell line in a PI3K-dependent manner. Real et al. (2007) showed that PKC $\zeta$ and PKCı were both required for T cell motility and the ability to scan DCs downstream of chemokine receptors.
PKC $\eta$

$\mathrm{PKC} \eta$ is classified into the novel PKC subfamily and shows a high sequence similarity to PKCE. It was originally isolated from a cDNA library of mouse skin in 1990 (Osada et al., 1990) and is localized on human chromosome 14 (Quan and Fisher, 1999) and mouse chromosome 12 (Chida et al., 1998). It is predominantly expressed in squamous epithelia including skin, tongue, esophagus, and trachea (Koizumi et al., 1993), but at high levels also in T and B cells (Mischak et al., 1991). In addition to phosphatidylserine and diacylglycerol, PKC $\eta$ can be specifically activated by cholesterol sulfate (Ikuta et al., 1994). An involvement in keratinocyte cell growth, terminal differentiation, and cell cycle arrest has been reported by several studies: PKC $\eta$ was shown to associate with and to activate Fyn, leading to keratinocyte growth arrest and differentiation (Cabodi et al., 2000); a PKC $\eta$ induced terminal differentiation through a transcriptional activation of TGas 1 and involucrin was described by Ueda et al. (1996) and Efimova and Eckert (2000). In addition, PKC $\eta$ has been shown to induce G1 arrest in keratinocytes via an inhibition of cyclin-dependent kinase 2 activity (Kashiwagi et al., 2000). An important role in the regulation of cell division and cell death during early B cell development was postulated by the work from Morrow et al. (1999).

The different lipid raft localization pattern of $\mathrm{PKC} \alpha, \mathrm{PKC} \eta$, and PKC $\theta$ in cisplatin-induced apoptotic Jurkat $\mathrm{T}$ cells was investigated by Solstad etal. (2010). A selective upregulation of PKC $\alpha$ in these microdomains upon apoptosis induction was revealed, whereas the levels of $\mathrm{PKC} \eta$ and $\mathrm{PKC} \theta$ were significantly reduced.

Recently, Fu et al. (2011) found a pivotal role of PKC $\eta$ in T cell activation and homeostatic proliferation. Comparing the phenotypes of $\mathrm{PKC}^{-/-}, \mathrm{PKC}^{-/-}$, and mice with a targeted disruption of both PKC isoforms, they were able to show that both isoforms share some redundancy in T cell biology. Both isoforms are recruited to the immunological synapse upon TCR stimulation and double-knockout mice showed a more severe defect in positive selection. Additionally, they found specific non-redundant functions as in self-antigen-dependent homeostatic proliferation. Using a live imaging approach a TCR-induced recruitment of GFP fusion proteins of $\mathrm{PKC} \eta$ and $\mathrm{PKC} \varepsilon$ to the plasma membrane was also described by Quann et al. (2011). The timely well coordinated localized enrichment of these two isoforms served as a prerequisite for the subsequent translocation of PKC $\theta$ to the center of the immunological synapse, necessary for the regulation of $\mathrm{T}$ cell polarity and $\mathrm{T}$ cell effector functions.

\section{PKC $\beta$}

The alternative splicing forms PKC $\beta$ I and PKC $\beta I$ II are members of the calcium-activated, phospholipid- and DAG-dependent classical or conventional PKC subfamily. Numerous studies have shown their role in various cellular processes, such as the regulation of B cell development and activation/proliferation, oxidative stressinduced apoptosis, androgen receptor-dependent transcription regulation, insulin signaling, and endothelial cell proliferation. In B cells, a signaling link between PKC $\beta$ and BTK has been described; PKC $\beta$ can downregulate BTK function through the direct phosphorylation of BTK at Ser-180, inhibiting its membrane translocation and subsequent activation (Kang et al., 2001). A key 
role for PKC $\beta$ in BCR-induced NF- $\mathrm{BB}$ activation has been shown (Sommer et al., 2005); the direct phosphorylation of CARMA1 at three serines within its linker region induced its translocation into lipid rafts, the recruitment of BCL10/Malt1 and the subsequent activation of signaling molecules downstream of the CBM complex. Furthermore, PKC $\beta$ seems to play an important, even dual role in insulin signaling pathways: in muscle cells, PKC $\beta$ mediates insulin-dependent DNA synthesis through the RAF1-MAPK/ERK signaling cascade downstream of insulin receptor substrate 1 (IRS1), and in adipocytes, it negatively regulates glucose transport by inhibiting the translocation of the glucose transporters GLUT1 and GLUT4 (Formisano et al., 2000; Bosch et al., 2003; Perrini et al., 2004).

A selective impact of $\mathrm{PKC} \beta$ on $\mathrm{T}$ cell migration has been shown by several studies (Volkov et al., 1998, 2001). LFA-1-triggered T cell locomotion led to the specific recruitment of PKC $\beta$ and $\mathrm{PKC} \delta$ to the MTOC and microtubules. A PKC $\beta$-deficient T cell line was unable to either crawl or develop a polarized microtubule array upon integrin cross-linking, whereas the ability to adhere and form actin-based pseudopodia remained unaffected. The reconstitution of $\mathrm{PKC} \beta(\mathrm{I})$ in non-motile $\mathrm{PKC} \beta$-deficient $\mathrm{T}$ cells restored their locomotory behavior in response to an LFA-1 signal.

The possible involvement of PKC $\beta$ in IL-2 gene transcription and/or IL-2 protein secretion upon TCR/CD28-induced T cell activation has been addressed by several studies (Long et al., 2001; Dreikhausen et al., 2003). The downregulation of PKC $\beta$ synthesis in Jurkat $\mathrm{T}$ cells via the addition of antisense oligos resulted in the suppression of the activation of MAPK/NF- $\mathrm{B} / \mathrm{NFAT}$ pathways and a complete inhibition of IL-2 transcription and secretion. However, a study performed with a PKC $\beta$-deficient HUT78 T cell clone excluded a possible role for IL-2 transcription and translation but demonstrated an involvement of PKC $\beta$ in IL-2 exocytosis. Thuille et al. (2004) investigated the physiological role of PKC $\beta$ in primary mouse T cells employing a PKC $\beta$-deficient knockout line and found mostly normal activation-induced proliferation and IL-2 secretion responses. However, it is conceivable that other members of the $\mathrm{P}$ PKC family, such $\mathrm{PKC} \alpha$, could compensate for the lack of this redundant PKC isotype in T cells.

In 2010 a re-investigation of IL-2 expression in PKC $\beta$ silenced Jurkat T cells via antisense RNA technology revealed a stimulation dependent decreased IL-2 production, whereas the CD25 expression was significantly increased. In addition, PKC $\beta$ loss of function affected also CD69 surface levels and IL-8 production (Cervino etal., 2010). In the same year a scientific group investigated the influence of PKC $\beta$ on PMA induced apoptosis protection in Jurkat T cells and HL-60 human leukemia cells. The downregulation of $\mathrm{PKC} \beta$ via shRNA or the specific small inhibitor enzastaurin reversed PMA induced protection of cell death (Meng et al., 2010).

\section{PKC $\alpha$}

Additional to $\mathrm{PKC} \theta$ also $\mathrm{PKC} \alpha$, a member of the conventional PKCs plays an important role in the induction of a robust immune response. By transfecting fetal thymuses with constitutively active and dominant-negative forms of PKC $\alpha$, Michie et al. (2001) showed that this isoform plays a specific role in the differentiation and expansion of immature thymocytes.
Iwamoto et al. (1992) established a transgenic mouse line carrying rabbit PKC $\alpha$ cDNA under the control of the regulatory element of human CD2. In response to stimulation with anti-CD3, they found that the transgenic thymocytes proliferated extensively and produced IL-2 (Iwamoto et al., 1992). Lallena et al. (1999) and Trushin et al. (2003) showed that PKC $\alpha$ regulates ІкB kinase and NF- $\kappa$ B in T cells.

$\mathrm{PKC} \alpha$ was shown to be involved in the activation of the PI3K/Akt pathway, which is involved in T cell development, survival, and migration (Jones et al., 2000; Haxhinasto et al., 2008; Sauer et al., 2008). Using PKC inhibitors and in vitro kinase assays with recombinant inactive Akt as a substrate, Yang et al. (2006) showed that PKC $\alpha$ could phosphorylate Akt at Ser ${ }^{473}$ dependent on TCR activation. These authors also performed knockdown analysis in Jurkat T cells and found decreased TCR-induced phosphorylation of Akt at Ser ${ }^{473}$. PKC $\alpha$ and PKC $\theta$ are both involved in TCR downregulation (von Essen et al., 2006). von Essen et al. (2006) investigated the role of PKC isotypes in TCR downregulation and found an important role for PKC $\alpha$ in TCR comodulation (downregulation of non-engaged TCRs). Moreover, PKC $\alpha$ seemed to be responsible for the induction of endocytosis of non-engaged TCRs that recycle to the contact zone between the $\mathrm{T}$ cell and the APC. PKC $\theta$, however, seemed to be responsible for inducing the endocytosis of directly triggered TCRs at the contact zone. Furthermore, a study showed the involvement of PKC $\alpha$ in allergic processes (Oh et al., 2004).

Our laboratory identified PKC $\alpha$ as a physiological and nonredundant $\mathrm{PKC}$ isotype in signaling pathways that are necessary for $\mathrm{T}$ cell-dependent IFN $\gamma$ production and IgG2a/2b antibody responses using PKC $\alpha$-knockout mice (Pfeifhofer et al., 2006).

\section{PKC LMWI (LOW-MOLECULAR-WEIGHT INHIBITOR) IN THE CLINIC}

Studies have shown that $\mathrm{PKC} \theta^{-/-}$mice fail to develop experimental allergic encephalomyelitis (EAE) and display drastically reduced lung inflammation after the induction of allergic asthma and alloreactivity in TX medicine, suggesting that $\mathrm{PKC} \theta$ by itself is an attractive monotarget for modulation of the immune response. While this published evidence validates PKC $\theta$ inhibition being essential, more recent results have indicated that additional PKC isotypes are involved in critical $\mathrm{T}$ cell signaling pathways. Because $\mathrm{PKC} \theta$ and PKC $\alpha$ are both highly expressed in T cells (GNF SymAtlas (http://symatlas.gnf.org/SymAtlas) and have isotype-selective functions in T cells (Sun et al., 2000; Pfeifhofer et al., 2003, 2006), whether $\mathrm{PKC} \theta$ and $\mathrm{PKC} \alpha$ also exert overlapping functions has also been investigated. Gruber et al. (2009b) generated PKC $\alpha^{-/-} \theta^{-/-}$ double-knockout mice and found that the NFAT pathway plays a predominant role in the collaborative action of PKC $\theta$ and PKC $\alpha$. The NFAT kinase GSK3 $\beta$ was hyper-reactive in $\mathrm{PKC} \alpha^{-/-} \theta^{-/-}$ double-knockout $\mathrm{CD}^{+}$T cells. Subsequently, these authors found reduced nuclear translocation and DNA binding of NFAT. In in vivo studies, $\mathrm{PKC} \alpha^{-/-} \theta^{-/-}$double-knockout $\mathrm{T}$ cells showed strongly reduced IL-2 cytokine secretion after injection of an anti-CD3 monoclonal antibody. Additionally, the mice showed an impaired alloimmune response, leading to significantly prolonged allograft survival in heart transplantation experiments (Gruber et al., 2009b). 
To obtain complete immunosuppressive effects, the inhibition of more than PKC $\theta$ appears to be needed, and the pharmacologic inhibition of multiple PKC isotypes may provide a successful approach to avert $\mathrm{T}$ cell effector functions that are relevant for diseases such as psoriasis, atopic dermatitis, and allergies, as well as other indications, including asthma, rheumatoid arthritis, multiple sclerosis, and transplant rejections.

Sotrastaurin (AEB071) is an immunosuppressive drug that inhibits multiple classical and novel members of the PKC family, resulting in decreased T lymphocyte activation (Evenou et al., 2009). In primary human and mouse $T$ cells, AEB071 abrogated IL-2 secretion and CD25 expression, which are markers of early $\mathrm{T}$ cell activation. $\mathrm{CD} 3 / \mathrm{CD} 28$-induced $\mathrm{T}$ cell proliferation, and LFA-1-mediated $\mathrm{T}$ cell adhesion were potently inhibited, and unlike previous PKC inhibitors, the apoptosis of murine T cell blasts was not enhanced (Evenou et al., 2009). These mechanistic studies on NF- $\mathrm{BB}$ and NFAT transcription factor transactivation additionally suggest that AEB071 and CsA have a complementary effect, resulting in the combined inhibition of IL-2 secretion. Additionally, other results suggest that AEB071 but not CsA inhibits the adhesive capacities of $\mathrm{T}$ lymphocytes.

Skvara et al. (2008) performed a clinical study with patients suffering from psoriasis in which the patients received single and multiple oral doses of AEB071. They found a strong reduction in the clinical severity of psoriasis and a histological improvement in skin lesions, indicating that sotrastaurin may provide a new therapeutic option for psoriasis (Skvara etal., 2008). Even so, we cannot exclude additional PKC isotypes being involved in critical $\mathrm{T}$ cell signaling pathways. The effect of AEB071 on PKC $\theta$, including other classical and novel PKC family members expressed in T cells, is the likely mechanism responsible for the strong AEB071 immunosuppressive activity.

\section{REFERENCES}

Akita, Y. (2002). Protein kinase C- $\varepsilon$ : its unique structure and function. $J$. Biochem. 132, 847-852.

Barreiro Arcos, M. L., Gorelik, G., Klecha, A., Genaro, A. M., and Cremaschi, G. A. (2006). Thyroid hormones increase inducible nitric oxide synthase gene expression downstream from $\mathrm{PKC} \zeta$ in murine tumor T lymphocytes. Am. J. Physiol. Cell Physiol. 291, C327-C336.

Bauer, B., Krumbock, N., Fresser, F., Hochholdinger, F., Spitaler, M., Simm, A., Uberall, F., Schraven, B., and Baier, G. (2001). Complex formation and cooperation of protein kinase $\mathrm{C} \theta$ and Akt1/protein kinase B $\alpha$ in the NF- $\kappa$ B transactivation cascade in Jurkat T cells. J. Biol. Chem. 276, 31627-31634.

Bertolotto, C., Maulon, L., Filippa, N., Baier, G., and Auberger, P. (2000). Protein kinase $\mathrm{C} \theta$ and $\varepsilon$ promote Tcell survival by a rsk-dependent phosphorylation and inactivation of BAD. J. Biol. Chem. 275, 37246-37250.
Bi, K., Tanaka, Y., Coudronniere, N., Sugie, K., Hong, S., Van Stipdonk, M. J., and Altman, A. (2001). Antigeninduced translocation of PKC $\theta$ to membrane rafts is required for $\mathrm{T}$ cell activation. Nat. Immunol. 2, 556-563.

Bosch, R. R., Bazuine, M., Wake, M. M., Span, P. N., Olthaar, A. J., Schurmann, A., Maassen, J. A., Hermus, A. R., Willems, P. H., and Sweep, C. G. (2003). Inhibition of protein kinase $\mathrm{C} \beta \mathrm{II}$ increases glucose uptake in 3T3-L1 adipocytes through elevated expression of glucose brane. Mol. Endocrinol. 17, 12301239.

Cabodi, S., Calautti, E., Talora, C., Kuroki, T., Stein, P. L., and Dotto, G. P. (2000). A PKCeta/Fyn-dependent pathway leading to keratinocyte growth arrest and differentiation. Mol. Cell 6, 11211129.

Carman, C. V., and Springer, T. A. (2003). Integrin avidity regulation: transporter 1 at the plasma mem-

\section{NEW CANDIDATE EFFECTOR PATHWAYS MEDIATED}

\section{BY PKC IN T CELLS}

The challenge ahead for immunologists is the further elucidation of the molecular and cellular processes of PKC $\alpha$ and PKC $\theta$ that govern the development and function of $\mathrm{T}$ cells. PKC-mediated signaling in NFAT/AP-1 transactivation critically involves a pathway of the orphan nuclear receptor NR2F6. There is evidence that PKC-induced signaling involves NR2F6 inactivation, presumably by stimulating the release of NR2F6 from DNAbinding sites. This inactivation facilitates NFAT/AP-1 binding to its enhancers in the IL-2 and IL-17A promoters. In agreement, $\mathrm{PKC} \alpha^{-1-} / \theta^{-/-}$double-knockout $\mathrm{T}$ cells show almost no TCR/NFAT/AP-1 transactivation signaling (Gruber et al., 2009b), whereas NR2F6-knockout $\mathrm{T}$ cells show markedly upregulated TCR/NFAT/AP-1 transactivation (Hermann-Kleiter et al., 2008). However, PKC $\alpha$ and PKC $\theta$ might have an even broader role in regulating $\mathrm{T}$ cell functions than just acting downstream of $\mathrm{T}$ cell antigen receptors. Thus, despite the significant progress in assembling the PKC puzzle in T lymphocytes, defining downstream PKC substrates, including their effector functions, triggered by this phosphorylation step remains to be investigated in physiological settings. From these investigations, innovative possibilities are likely to emerge for the manipulation of $\mathrm{T}$ cell pathways in treating immunological diseases by suppressing pathophysiological immune responses or augmenting host-protective immunity.

\section{ACKNOWLEDGMENTS}

This work was supported by grants from the FWF Austrian Science Fund (SFB-021, T264-B13, P19505-B05 and P25044), funds from the Austrian BM:WF and the European Community Program SYBILLA under grant agreement HEALTH-F4-2008201106).

are changes in affinity and conformation underemphasized? Curr. Opin. Cell Biol. 15, 547-556.

Castrillo, A., Pennington, D. J., Otto, F., Parker, P. J., Owen, M. J., and Boscá, L. (2001). Protein kinase Cepsilon is required for macrophage activation and defense against bacterial infection. J. Exp. Med. 194, 1231-1242.

Cerda, S. R., Bissonnette, M., ScaglioneSewell, B., Lyons, M. R., Khare, S., Mustafi, R., and Brasitus, T. A. (2001). PKC $\delta$ inhibits anchorage-dependent and -independent growth, enhances differentiation, and increases apoptosis in CaCo-2 cells. Gastroenterology 120, 1700-1712.

Cervino, M. C., Lopez-Lago, M. A., Vinuela, J. E., and Barja, P. (2010). Specific inhibition of protein kinase Cbeta expression by antisense RNA affects the activation of Jurkat T lymphoma cells. J. Biol. Regul. Homeost. Agents 24, 273-285.

Chida, K., Hara, T., Hirai, T., Konishi, C., Nakamura, K., Nakao, K., Aiba, A., Katsuki, M., and Kuroki, T. (2003).
Disruption of protein kinase Ceta results in impairment of wound healing and enhancement of tumor formation in mouse skin carcinogenesis. Cancer Res. 63, 2404-2408.

Chida, K., Nakada, T., Otsuka, H., Kuroki, T., and Satoh, H. (1998). Assignment of protein kinase $\mathrm{C}$ eta (Pkch) to mouse chromosome band 12C3-D2 by in situ hybridization. Cytogenet. Cell Genet. 82, 30-31.

Chuang, H. C., Lan, J. L., Chen, D. Y., Yang, C. Y., Chen, Y. M., Li, J. P., Huang, C. Y., Liu, P. E., Wang, X., Tan, T. H. (2011). The kinase GLK controls autoimmunity and NF- $\kappa \mathrm{B}$ signaling by activating the kinase PKC- $\theta$ in $\mathrm{T}$ cells. Nat. Immunol. 12, 1113-1118.

Denis, F. M., Benecke, A., Di Gioia, Y., Touw, I. P., Cayre, Y. E., and Lutz, P. G. (2005). PRAM-1 potentiates arsenic trioxide-induced JNK activation. J. Biol. Chem. 280, 9043-9048.

Dreikhausen, U. E., Gorf, K., Resch, K., and Szamel, M. (2003). Protein kinase $C \beta 1$, a major regulator of 
TCR-CD28-activated signal transduction leading to IL-2 gene transcription and secretion. Int. Immunol. 15, 1089-1098.

Duchniewicz, M., Zemojtel, T., Kolanczyk, M., Grossmann, S., Scheele, J. S., and Zwartkruis, F. J. (2006). Rap1A-deficient T and B cells show impaired integrin-mediated cell adhesion. Mol. Cell. Biol. 26, 643-653.

Dustin, M. L. (2008). T-cell activation through immunological synapses and kinapses. Immunol. Rev. 221, 77-89.

Dustin, M. L., Bivona, T. G., and Philips, M. R. (2004). Membranes as messengers in T cell adhesion signaling. Nat. Immunol. 5, 363-372.

Dustin, M. L., and Springer, T. A. (1989). T-cell receptor crosslinking transiently stimulates adhesiveness through LFA-1. Nature 341, 619-624.

Efimova, T., and Eckert, R. L. (2000). Regulation of human involucrin promoter activity by novel protein kinase C isoforms. J. Biol. Chem. 275, 1601-1607.

Evenou, J. P., Wagner, J., Zenke, G., Brinkmann, V., Wagner, K., Kovarik, J., Welzenbach, K. A., Weitz-Schmidt, G., Guntermann, C., Towbin, H., Cottens, S., Kaminski, S., Letschka, T., Lutz-Nicoladoni, C., Gruber, T., Hermann-Kleiter, N., Thuille, N., and Baier, G. (2009). The potent protein kinase C-selective inhibitor AEB071 (sotrastaurin) represents a new class of immunosuppressive agents affecting early T-cell activation. J. Pharmacol. Exp. Ther. 330, 792-801.

Fang, D., and Liu, Y. C. (2001). Proteolysis-independent regulation of PI3K by Cbl-b-mediated ubiquitination in T cells. Nat. Immunol. 2, 870-875.

Fauconnier, M., Bourigault, M. L., Meme, S., Szeremeta, F., Palomo, J., Danneels, A., Charron, S., Fick, L., Jacobs, M., Beloeil, J. C., Ryffel, B., and Quesniaux, V. F. (2011). Protein kinase $\mathrm{C}-\theta$ is required for development of experimental cerebral malaria. Am. J. Pathol. 178, 212-221.

Formisano, P., Oriente, F., Fiory, F., Caruso, M., Miele, C., Maitan, M. A., Andreozzi, F., Vigliotta, G., Condorelli, G., and Beguinot, F. (2000). Insulin-activated protein kinase $C \beta$ bypasses Ras and stimulates mitogenactivated protein kinase activity and cell proliferation in muscle cells. Mol. Cell. Biol. 20, 6323-6333.

Freeley, M., Volkov, Y., Kelleher, D., and Long, A. (2005). Stimulusinduced phosphorylation of PKC $\theta$ at the C-terminal hydrophobicmotif in human $\mathrm{T}$ lymphocytes. Biochem. Biophys. Res. Commun. 334, 619-630.

Freiberg, B. A., Kupfer, H., Maslanik, W., Delli, J., Kappler, J., Zaller, D. M., and Kupfer, A. (2002). Staging and resetting $\mathrm{T}$ cell activation in SMACs. Nat. Immunol. 3, 911-917.

Fu, G., Hu, J., Niederberger-Magnenat, N., Rybakin, V., Casas, J., Yachi, P. P. Feldstein, S., Ma, B., Hoerter, J. A., Ampudia, J., Rigaud, S., Lambolez, F., Gavin, A. L., Sauer, K., Cheroutre, H., and Gascoigne, N. R. (2011). Protein kinase $\mathrm{C}$ eta is required for $\mathrm{T}$ cell activation and homeostatic proliferation. Sci. Signal. 4, ra84.

Garaude, J., Kaminski, S., Charni, S., Aguilo, J. I., Jacquet, C., Plays, M., Hernandez, J., Rodriguez, F., Hipskind, R. A., Anel, A., and Villalba, M. (2008). Impaired anti-leukemic immune response in $\mathrm{PKC} \theta$-deficient mice. Mol. Immunol. 45, 34633469.

Genot, E. M., Parker, P. J., and Cantrell, D. A. (1995). Analysis of the role of protein kinase $\mathrm{C}-\alpha,-\varepsilon$, and $-\zeta$ in $\mathrm{T}$ cell activation. J. Biol. Chem. 270, 9833-9839.

Gomez, J., Martinez, C., Garcia, A., and Rebollo, A. (1996). Association of phosphatidylinositol 3 kinase to protein kinase $\mathrm{C} \zeta$ during interleukin2 stimulation. Eur. J. Immunol. 26, 1781-1787.

Gomez, J., Martinez De Aragon, A., Bonay, P., Pitton, C., Garcia, A., Silva, A., Fresno, M., Alvarez, F., and Rebollo, A. (1995). Physical association and functional relationship between protein kinase $\mathrm{C} \zeta$ and the actin cytoskeleton. Eur. J. Immunol. 25, 2673-2678.

Gorelik, G., Fang, J. Y., Wu, A., Sawalha, A. H., and Richardson, B. (2007). Impaired $\mathrm{T}$ cell protein kinase $\mathrm{C} \delta$ activation decreases ERK pathway signaling in idiopathic and hydralazine-induced lupus. J. Immunol. 179, 55535563.

Graeler, M. H., Kong, Y., Karliner, J. S., and Goetzl, E. J. (2003). Protein kinase $\mathrm{C} \varepsilon$ dependence of the recovery from down-regulation of S1P1 G protein-coupled receptors of T lymphocytes. J. Biol. Chem. 278, 27737-27741.

Gruber, T., Barsig, J., Pfeifhofer, C., Ghaffari-Tabrizi, N., Tinhofer, I., Leitges, M., and Baier, G. (2005). PKC $\delta$ is involved in signal attenuation in CD3+ T cells. Immunol. Lett. 96, 291-293.

Gruber, T., Fresser, F., Jenny, M., Uberall, F., Leitges, M., and
Baier, G. (2008). PKC $\theta$ cooperates with atypical $\mathrm{PKC} \zeta$ and $\mathrm{PKC}$ in NF- $\mathrm{B}$ transactivation of $\mathrm{T}$ lymphocytes. Mol. Immunol. 45 117-126.

Gruber, T., Hermann-Kleiter, N., Hinterleitner, R., Fresser, F., Schneider, R., Gastl, G., Penninger, J. M., and Baier, G. (2009a). PKC $\theta$ modulates the strength of $\mathrm{T}$ cell responses by targeting Cbl-b for ubiquitination and degradation. Sci. Signal. 2, ra30.

Gruber, T., Hermann-Kleiter, N., Pfeifhofer-Obermair, C., LutzNicoladoni, C., Thuille, N., Letschka, T., Barsig, J., Baudler, M., Li, J., Metzler, B., Nusslein-Hildesheim, B., Wagner, J., Leitges, M., and Baier, G. (2009b). PKC $\theta$ cooperates with PKC $\alpha$ in alloimmune responses of $\mathrm{T}$ cells in vivo. Mol. Immunol. 46, 2071-2079.

Gruber, T., Pfeifhofer-Obermair, C., and Baier, G. (2010). PKC $\theta$ is necessary for efficient activation of $\mathrm{NFkB}$ NFAT, and AP-1 during positive selection of thymocytes. Immunol. Lett. 132, 6-11.

Gunaratne, A., Benchabane, H., and Di Guglielmo, G. M. (2012). Regulation of TGF $\beta$ receptor trafficking and signaling by atypical protein kinase C. Cell Signal. 24, 119-130.

Gupta, S., Manicassamy, S., Vasu, C., Kumar, A., Shang, W., and Sun, Z. (2008a). Differential requirement of PKC $\theta$ in the development and function of natural regulatory T cells. Mol. Immunol. 46, 213-224.

Gupta, S., Shang, W., and Sun, Z. (2008b). Mechanisms regulating the development and function of natural regulatory T cells. Arch. Immunol. Ther. Exp. (Warsz) 56, 85-102.

Haxhinasto, S., Mathis, D., and Benoist, C. (2008). The AKT-mTOR axis regulates de novo differentiation of CD $4^{+}$Foxp $3^{+}$cells. J. Exp. Med. 205, 565-574.

Heissmeyer, V., Macian, F., Im, S. H., Varma, R., Feske, S., Venuprasad, K., Gu, H., Liu, Y. C., Dustin, M. L., and Rao, A. (2004). Calcineurin imposes $\mathrm{T}$ cell unresponsiveness through targeted proteolysis of signaling proteins. Nat. Immunol. 5 , 255-265.

Hermann-Kleiter, N., Gruber, T., LutzNicoladoni, C., Thuille, N., Fresser, F., Labi, V., Schiefermeier, N., Warnecke, M., Huber, L., Villunger, A., Eichele, G., Kaminski, S., and Baier, G. (2008). The nuclear orphan receptor NR2F6 suppresses lymphocyte activation and $\mathrm{T}$ helper 17-dependent autoimmunity. Immunity 29, 205-216.
Hii, C. S., Costabile, M., Mayne, G. C., Der, C. J., Murray, A. W., and Ferrante, A. (2003). Selective deficiency in protein kinase $\mathrm{C}$ isoenzyme expression and inadequacy in mitogenactivated protein kinase activation in cord blood T cells. Biochem. J. 370, 497-503.

Hirai, T., and Chida, K. (2003). Protein kinase $\mathrm{C} \zeta(\mathrm{PKC} \zeta)$ : activation mechanisms and cellular functions. J. Biochem. 133, 1-7.

Hsieh, H. L., Wang, H. H., Wu, C. Y., Jou, M. J., Yen, M. H., Parker, P., and Yang, C. M. (2007). BK-induced COX-2 expression via $\mathrm{PKC} \delta$-dependent activation of $\mathrm{p} 42 / \mathrm{p} 44 \mathrm{MAPK}$ and NF$\kappa \mathrm{B}$ in astrocytes. Cell Signal. 19, 330-340.

Ikuta, T., Chida, K., Tajima, O., Matsuura, Y., Iwamori, M., Ueda, Y., Mizuno, K., Ohno, S., and Kuroki, T. (1994). Cholesterol sulfate, a novel activator for the eta isoform of protein kinase C. Cell Growth Differ. 5, 943-947.

Iwamoto, T., Hagiwara, M., Hidaka, H., Isomura, T., Kioussis, D., and Nakashima, I. (1992). Accelerated proliferation and interleukin-2 production of thymocytes by stimulation of soluble anti-CD3 monoclonal antibody in transgenic mice carrying a rabbit protein kinase $\mathrm{C} \alpha$. J. Biol. Chem. 267, 18644-18648.

Jackson, D., Zheng, Y., Lyo, D., Shen, Y., Nakayama, K., Nakayama, K. I., Humphries, M. J., Reyland, M. E., and Foster, D. A. (2005). Suppression of cell migration by protein kinase $\mathrm{C} \delta$. Oncogene 24, 3067-3072.

Jeon, M. S., Atfield, A., Venuprasad, K., Krawczyk, C., Sarao, R., Elly, C., Yang, C., Arya, S., Bachmaier, K., Su, L., Bouchard, D., Jones, R., Gronski, M., Ohashi, P., Wada, T., Bloom, D., Fathman, C. G., Liu, Y. C., and Penninger, J. M. (2004). Essential role of the E3 ubiquitin ligase Cbl-b in T cell anergy induction. Immunity 21 , 167-177.

Jones, R. G., Parsons, M., Bonnard, M., Chan, V. S., Yeh, W. C., Woodgett, J. R., and Ohashi, P. S. (2000). Protein kinase $\mathrm{B}$ regulates $\mathrm{T}$ lymphocyte survival, nuclear factor $\kappa \mathrm{B}$ activation, and $\mathrm{Bcl}-\mathrm{X}(\mathrm{L})$ levels in vivo. J. Exp. Med. 191, 1721-1734.

Kang, S. W., Wahl, M. I., Chu, J., Kitaura, J., Kawakami, Y., Kato, R. M., Tabuchi, R., Tarakhovsky, A., Kawakami, T., Turck, C. W., Witte, O. N., and Rawlings, D. J. (2001). PKC $\beta$ modulates antigen receptor signaling via regulation of Btk membrane localization. EMBO J. 20, 5692-5702.

Kashiwagi, M., Ohba, M., Watanabe, H., Ishino, K., Kasahara, K., 
Sanai, Y., Taya, Y., and Kuroki, T. (2000). PKCeta associates with cyclin E/cdk2/p21 complex, phosphorylates p21 and inhibits cdk2 kinase in keratinocytes. Oncogene 19, 6334-6341.

Katagiri, K., Hattori, M., Minato, N., and Kinashi, T. (2002). Rapl functions as a key regulator of T-cell and antigen-presenting cell interactions and modulates T-cell responses. $\mathrm{Mol}$. Cell. Biol. 22, 1001-1015.

Keenan, C., Volkov, Y., Kelleher, D., and Long, A. (1997). Subcellular localization and translocation of protein kinase $\mathrm{C}$ isoforms $\zeta$ and $\varepsilon$ in human peripheral blood lymphocytes. Int. Immunol. 9, 1431-1439.

Kikkawa, U., Matsuzaki, H., and Yamamoto, T. (2002). Protein kinase C $\delta$ (PKC $\delta)$ : activation mechanisms and functions. J. Biochem. 132, 831-839.

Koizumi, H., Kohno, Y., Osada, S., Ohno, S., Ohkawara, A., and Kuroki, T. (1993). Differentiation-associated localization of nPKC eta, a $\mathrm{Ca}(++)$ independent protein kinase $\mathrm{C}$, in normal human skin and skin diseases. J. Invest. Dermatol. 101, 858-863.

Kong, K. F., Yokosuka, T., CanonigoBalancio, A. J., Isakov, N., Saito, T., and Altman, A. (2011). A motif in the V3 domain of the kinase PKC $\theta$ determines its localization in the immunological synapse and functions in $\mathrm{T}$ cells via association with CD28. Nat. Immunol. 12, 1105-1112.

Kumar, S., Sieghart, W., and Morrow, A. L. (2002). Association of protein kinase $\mathrm{C}$ with $\mathrm{GABA}(\mathrm{A})$ receptors containing alphal and alpha4 subunits in the cerebral cortex: selective effects of chronic ethanol consumption. J. Neurochem. 82, 110-117.

Kwon, M. J., Ma, J., Ding, Y., Wang, R., and Sun, Z. (2012). Protein kinase C$\theta$ promotes Th17 differentiation via upregulation of Stat3. J. Immunol. 188, 5887-5897.

Lallena, M. J., Diaz-Meco, M. T., Bren, G., Paya, C. V., and Moscat, J. (1999). Activation of IкB kinase $\beta$ by protein kinase C isoforms. Mol. Cell. Biol. 19, 2180-2188.

Lee, K. Y., D’Acquisto, F., Hayden, M. S., Shim, J. H., and Ghosh, S. (2005). PDK1 nucleates $\mathrm{T}$ cell receptor-induced signaling complex for NF- $\mathrm{B}$ activation. Science 308 , 114-118.

Leitges, M., Schmedt, C., Guinamard, R., Davoust, J., Schaal, S., Stabel, S., and Tarakhovsky, A. (1996). Immunodeficiency in protein kinase cbeta-deficient mice. Science 273, 788-791.
Leroy, I., De Thonel, A., Laurent, G. and Quillet-Mary, A. (2005). Protein kinase $\mathrm{C} \zeta$ associates with death inducing signaling complex and regulates Fas ligand-induced apoptosis. Cell Signal. 17, 1149-1157.

Letschka, T., Kollmann, V., PfeifhoferObermair, C., Lutz-Nicoladoni, C. Obermair, G. J., Fresser, F., Leitges, M., Hermann-Kleiter, N., Kaminski, S., and Baier, G. (2008). PKCO selectively controls the adhesionstimulating molecule Rap1. Blood 112, 4617-4627.

Li, L., Lorenzo, P. S., Bogi, K., Blumberg, P. M., and Yuspa, S. H. (1999). Protein kinase $\mathrm{C} \delta$ targets mitochondria, alters mitochondrial membrane potential, and induces apoptosis in normal and neoplastic keratinocytes when overexpressed by an adenoviral vector. Mol. Cell. Biol. 19, 85478558.

Liu, Y., Graham, C., Li, A., Fisher, R. J., and Shaw, S. (2002). Phosphorylation of the protein kinase C- $\theta$ activation loop and hydrophobic motif regulates its kinase activity, but only activation loop phosphorylation is critical to in vivo nuclearfactor-кB induction. Biochem. J. 361 255-265.

Liu, Y., Witte, S., Liu, Y. C., Doyle, M., Elly, C., and Altman, A. (2000). Regulation of protein kinase $\mathrm{C} \theta$ function during $\mathrm{T}$ cell activation by Lck-mediated tyrosine phosphorylation. J. Biol. Chem. 275, 3603-3609.

Lomonaco, S. L., Kahana, S., Blass, M., Brody, Y., Okhrimenko, H., Xiang, C., Finniss, S., Blumberg, P. M., Lee, H. K., and Brodie, C. (2008). Phosphorylation of protein kinase $\mathrm{C} \delta$ on distinct tyrosine residues induces sustained activation of Erk1/2 via down-regulation of MKP-1: role in the apoptotic effect of etoposide. $J$. Biol. Chem. 283, 17731-17739.

Long, A., Kelleher, D., Lynch, S., and Volkov, Y. (2001). Cutting edge: protein kinase $C \beta$ expression is critical for export of Il-2 from T cells. J. Immunol. 167, 636-640.

Lu, W., Finnis, S., Xiang, C., Lee, H. K., Markowitz, Y., Okhrimenko, H., and Brodie, C. (2007). Tyrosine 311 is phosphorylated by c-Abl and promotes the apoptotic effect of PKC $\delta$ in glioma cells. Biochem. Biophys. Res. Commun. 352, 431-436.

Lub, M., Van Kooyk, Y., and Figdor, C. G. (1995). Ins and outs of LFA-1. Immunol. Today 16, 479-483.

Lutz-Nicoladoni, C., Letschka, T., Leitges, M., Villunger, A., and Baier, G. (2005). Essential role of PKC $\delta$ in apoptosis induction of mouse thymocytes. Am. J. Immunol. 1, 14-20.

Ma, J., Ding, Y., Fang, X., Wang, R., and Sun, Z. (2012). Protein kinase C$\theta$ inhibits inducible regulatory $\mathrm{T}$ cell differentiation via an AKT-Foxo1/3adependent pathway. J. Immunol. 188, 5337-5347.

Ma, J. S., Haydar, T. F., and Radoja, S. (2008). Protein kinase C $\delta$ localizes to secretory lysosomes in CD8+ CTL and directly mediates TCR sig nals leading to granule exocytosismediated cytotoxicity. J. Immunol. 181, 4716-4722.

Ma, J. S., Monu, N., Shen, D. T., Mecklenbrauker, I., Radoja, N., Haydar, T. F., Leitges, M., Frey, A. B., Vukmanovic, S., and Radoja, S. (2007). Protein kinase $\mathrm{C} \delta$ regulates antigen receptor-induced lytic granule polarization in mouse CD8+ CTL. J. Immunol. 178, 7814-7821.

Majumder, P. K., Mishra, N. C., Sun, X. Bharti, A., Kharbanda, S., Saxena, S., and Kufe, D. (2001). Targeting of protein kinase $\mathrm{C} \delta$ to mitochondria in the oxidative stress response. Cell Growth Differ. 12, 465-470.

Marsland, B. J., Soos, T. J., Spath, G., Littman, D. R., and Kopf, M. (2004). Protein kinase C $\theta$ is critical for the development of in vivo $\mathrm{T}$ helper (Th)2 cell but not Th1 cell responses. J. Exp. Med. 200 181-189.

Martin, A. G., San-Antonio, B., and Fresno, M. (2001). Regulation of nuclear factor $\kappa \mathrm{B}$ transactivation. Implication of phosphatidylinositol 3-kinase and protein kinase $\mathrm{C} \zeta$ in c-Rel activation by tumor necrosis factor $\alpha$. J. Biol. Chem. 276, 15840 15849.

Martin, P., Villares, R., RodriguezMascarenhas, S., Zaballos, A., Leitges, M., Kovac, J., Sizing, I., Rennert, P., Marquez, G., Martinez, A. C., Diaz Meco, M. T., and Moscat, J. (2005). Control of $\mathrm{T}$ helper 2 cell function and allergic airway inflammation by PKCל. Proc. Natl. Acad. Sci. U.S.A. 102, 9866-9871.

Maulon, L., Mari, B., Bertolotto, C., Ricci, J. E., Luciano, F., Belhacene, N., Deckert, M., Baier, G., and Auberger, P. (2001). Differential requirements for ERK1/2 and P38 MAPK activation by thrombin in $\mathrm{T}$ cells. Role of P59Fyn and PKCE. Oncogene 20, 1964-1972.

Mazerolles, F., Lumbroso, C., Lecomte, O., Le Deist, F., and Fischer, A. (1988). The role of lymphocyte functionassociated antigen 1 (LFA-1) in the adherence of $\mathrm{T}$ lymphocytes to $\mathrm{B}$ lymphocytes. Eur. J. Immunol. 18 1229-1234.
Meng, X. W., Heldebrant, M. P., Flatten, K. S., Loegering, D. A., Dai, H., Schneider, P. A., Gomez, T. S., Peterson, K. L., Trushin, S. A., Hess, A. D., Smith, B. D., Karp, J. E., Billadeau, D. D., and Kaufmann, S. H. (2010). Protein kinase Cbeta modulates ligandinduced cell surface death receptor accumulation: a mechanistic basis for enzastaurin-death ligand synergy. $J$. Biol. Chem. 285, 888-902.

Michie, A. M., Soh, J. W., Hawley, R. G., Weinstein, I. B., and Zuniga-Pflucker, J. C. (2001). Allelic exclusion and differentiation by protein kinase Cmediated signals in immature thymocytes. Proc. Natl. Acad. Sci. U.S.A. 98, 609-614.

Mirandola, P., Gobbi, G., Masselli, E., Micheloni, C., Di Marcantonio, D., Queirolo, V., Chiodera, P., Meschi, T., and Vitale, M. (2011). Protein kinase $\mathrm{C} \varepsilon$ regulates proliferation and cell sensitivity to TGF- $1 \beta$ of CD4+ T lymphocytes: implications for Hashimoto thyroiditis. J. Immunol. 187, 4721-4732.

Mischak, H., Kolch, W., Goodnight, J., Davidson, W. F., Rapp, U., RoseJohn, S., and Mushinski, J. F. (1991). Expression of protein kinase $\mathrm{C}$ genes in hemopoietic cells is cell-type- and B cell-differentiation stage specific. J. Immunol. 147, 3981-3987.

Miscia, S., Ciccocioppo, F., Lanuti, P., Velluto, L., Bascelli, A., Pierdomenico, L., Genovesi, D., Di Siena, A., Santavenere, E., Gambi, F., Ausili-Cefaro, G., Grimley, P. M., Marchisio, M., and Gambi, D. (2009). A $\beta(1-42)$ stimulated $\mathrm{T}$ cells express P-PKC $\delta$ and $\mathrm{P}-\mathrm{PKC} \zeta$ in Alzheimer disease. Neurobiol. Aging 30, 394-406.

Morley, S. C., Weber, K. S., Kao, H., and Allen, P. M. (2008). Protein kinase $\mathrm{C}-\theta$ is required for efficient positive selection. J. Immunol. 181, 4696-4708.

Morrow, T. A., Muljo, S. A., Zhang, J., Hardwick, J. M., and Schlissel, M. S. (1999). Pro-B-cell-specific transcription and proapoptotic function of protein kinase Ceta. Mol. Cell. Biol. 19, 5608-5618.

Nakagawa, M., Oliva, J. L., Kothapalli, D., Fournier, A., Assoian, R. K., and Kazanietz, M. G. (2005). Phorbol ester-induced G1 phase arrest selectively mediated by protein kinase $\mathrm{C} \delta$ dependent induction of p21. J. Biol. Chem. 280, 33926-33934.

Naramura, M., Jang, I. K., Kole, H., Huang, F., Haines, D., and $\mathrm{Gu}$, H. (2002). c-Cbl and Cbl$\mathrm{b}$ regulate $\mathrm{T}$ cell responsiveness by promoting ligand-induced TCR down-modulation. Nat. Immunol. 3, 1192-1199. 
Nechushtan, H., Leitges, M., Cohen, C., Kay, G., and Razin, E. (2000). Inhibition of degranulation and interleukin-6 production in mast cells derived from mice deficient in protein kinase Cbeta. Blood 95, 17521757.

Nishanth, G., Sakowicz-Burkiewicz, M., Handel, U., Kliche, S., Wang, X., Naumann, M., Deckert, M., and Schluter, D. (2010). Protective Toxoplasma gondii-specific Tcell responses require T-cell-specific expression of protein kinase C- $\theta$. Infect. Immun. 78, 3454-3464.

Oh, J. W., Kim, E. Y., Koo, B. S., Lee, H. B., Lee, K. S., Kim, Y. S., and Han, J. S. (2004). Der f 2 activates phospholipase D in human T lymphocytes from Dermatophagoides farinae specific allergic individuals: involvement of protein kinase C- $\alpha$. Exp. Mol. Med. 36, 486-492.

Osada, S., Mizuno, K., Saido, T. C., Akita, Y., Suzuki, K., Kuroki, T., and Ohno, S. (1990). A phorbol ester receptor/protein kinase, $\mathrm{nPKC}$ eta, a new member of the protein kinase $\mathrm{C}$ family predominantly expressed in lung and skin. J. Biol. Chem. 265, 22434-22440.

Penninger, J. M., and Crabtree, G. R. (1999). The actin cytoskeleton and lymphocyte activation. Cell 96, 9-12.

Perrini, S., Natalicchio, A., Laviola, L., Belsanti, G., Montrone, C., Cignarelli, A., Minielli, V., Grano, M., De Pergola, G., Giorgino, R., and Giorgino, F. (2004). Dehydroepiandrosterone stimulates glucose uptake in human and murine adipocytes by inducing GLUT1 and GLUT4 translocation to the plasma membrane. Diabetes 53, 41-52.

Pfeifhofer, C., Gruber, T., Letschka, T., Thuille, N., Lutz-Nicoladoni, C., Hermann-Kleiter, N., Braun, U., Leitges, M., and Baier, G. (2006). Defective IgG2a/2b class switching in PKC $\alpha-/-$ mice. J. Immunol. 176, 6004-6011.

Pfeifhofer, C., Kofler, K., Gruber, T., Tabrizi, N. G., Lutz, C., Maly, K., Leitges, M., and Baier, G. (2003). Protein kinase $\mathrm{C} \theta$ affects $\mathrm{Ca}^{2+}$ mobilization and NFAT cell activation in primary mouse T cells. J. Exp. Med. 197, 1525-1535.

Quan, T., and Fisher, G. J. (1999). Cloning and characterization of the human protein kinase C-eta promoter. J. Biol. Chem. 274, 2856628574

Quann, E. J., Liu, X., Altan-Bonnet, G., and Huse, M. (2011). A cascade of protein kinase $\mathrm{C}$ isozymes promotes cytoskeletal polarization in $\mathrm{T}$ cells. Nat. Immunol. 12, 647-654.

Rao, K. L., Varalakshmi, C., Kumari, A. L., and Khar, A. (1999). Interaction between B.7 and CD28 costimulatory molecules is essential for the activation of effector function mediating spontaneous tumour regression. Scand. J. Immunol. 49, 633-640.

Real, E., Faure, S., Donnadieu, E., and Delon, J. (2007). Cutting edge: atypical PKCs regulate $\mathrm{T}$ lymphocyte polarity and scanning behavior. J. Immunol. 179, 56495652.

Sakaguchi, S., Yamaguchi, T., Nomura, T., and Ono, M. (2008). Regulatory T cells and immune tolerance. Cell 133, 775-787.

Sakowicz-Burkiewicz, M., Nishanth, G. Helmuth, U., Drogemuller, K., Busch, D. H., Utermohlen, O., Naumann, M., Deckert, M., and Schluter, D. (2008). Protein kinase C- $\theta$ critically regulates the proliferation and survival of pathogen-specific $\mathrm{T}$ cells in murine listeriosis. J. Immunol. 180 5601-5612.

Salek-Ardakani, S., So, T., Halteman, B. S., Altman, A., and Croft, M. (2004). Differential regulation of Th2 and Th1 lung inflammatory responses by protein kinase $\mathrm{C} \theta$. J. Immunol. 173, 6440-6447.

Salek-Ardakani, S., So, T., Halteman, B. S., Altman, A., and Croft, M. (2005). Protein kinase C $\theta$ controls Th1 cells in experimental autoimmune encephalomyelitis. J. Immunol. 175, 7635-7641

San-Antonio, B., Iniguez, M. A., and Fresno, M. (2002). Protein kinase Cל phosphorylates nuclear factor of activated $\mathrm{T}$ cells and regulates its transactivating activity. J. Biol. Chem. 277, 27073-27080.

Sanchez-Valdepenas, C., Punzon, C., San-Antonio, B., Martin, A. G., and Fresno, M. (2007). Differential regulation of p65 and c-Rel NF- $\mathrm{BB}$ transactivating activity by Cot, protein kinase $\mathrm{C} \zeta$ and NIK protein kinases in CD3/CD28 activated T cells. Cell Signal. 19, 528-537.

Santiago-Walker, A. E., Fikaris, A. J., Kao, G. D., Brown, E. J., Kazanietz, M. G., and Meinkoth, J. L. (2005). Protein kinase C $\delta$ stimulates apoptosis by initiating G1 phase cell cycle progression and $S$ phase arrest. J. Biol. Chem. 280, 3210732114.

Satoh, A., Gukovskaya, A. S., Nieto, J. M., Cheng, J. H., Gukovsky, I., Reeve, J. R. Jr., Shimosegawa, T., and Pandol, S. J. (2004). PKC $\delta$ and $\varepsilon$ regulate NF- $\kappa \mathrm{B}$ activation induced by cholecystokinin and TNF- $\alpha$ in pancreatic acinar cells. Am. J. Physiol. Gastrointest. Liver Physiol. 287 G582-591.

Sauer, S., Bruno, L., Hertweck, A., Finlay, D., Leleu, M., Spivakov, M., Knight, Z. A., Cobb, B. S., Cantrell, D., O'Connor, E., Shokat, K. M., Fisher, A. G., and Merkenschlager, M. (2008). T cell receptor signaling controls Foxp3 expression via PI3K, Akt, and mTOR. Proc. Natl. Acad. Sci. U.S.A. 105, 7797-7802.

Schaefer, B. C., Kappler, J. W., Kupfer, A., and Marrack, P. (2004). Complex and dynamic redistribution of $\mathrm{NF}-\kappa \mathrm{B}$ signaling intermediates in response to $\mathrm{T}$ cell receptor stimulation. Proc. Natl. Acad. Sci. U.S.A. 101, 1004-1009.

Scheel-Toellner, D., Pilling, D., Akbar, A. N., Hardie, D., Lombardi, G., Salmon, M., and Lord, J. M. (1999). Inhibition of $\mathrm{T}$ cell apoptosis by IFN- $\beta$ rapidly reverses nuclear translocation of protein kinase C- $\delta$. Eur. J. Immunol. 29 2603-2612.

Shevach, E. M. (2009). Mechanisms of foxp3 $+\mathrm{T}$ regulatory cellmediated suppression. Immunity 30 , 636-645.

Shimonaka, M., Katagiri, K., Nakayama, T., Fujita, N., Tsuruo, T., Yoshie, O., and Kinashi, T. (2003). Rap1 translates chemokine signals to integrin activation, cell polarization, and motility across vascular endothelium under flow. J. Cell Biol. 161, 417-427.

Simon, A. K., Auphan, N., Pophillat, M., Boyer, C., Ghosh, S., Rincon, M., Flavell, R. A., and SchmittVerhulst, A. M. (2000). The lack of NF- $\mathrm{B}$ transactivation and $\mathrm{PKC}$ $\varepsilon$ expression in $\mathrm{CD} 4(+) \mathrm{CD} 8(+)$ thymocytes correlates with negative selection. Cell Death Differ. 7, 1253-1262.

Skvara, H., Dawid, M., Kleyn, E., Wolff, B., Meingassner, J. G., Knight, H., Dumortier, T., Kopp, T., Fallahi, N., Stary, G., Burkhart, C., Grenet, O. Wagner, J., Hijazi, Y., Morris, R. E., Mcgeown, C., Rordorf, C., Griffiths, C. E., Stingl, G., and Jung, T. (2008). The PKC inhibitor AEB071 may be a therapeutic option for psoriasis. J. Clin. Invest. 118, 31513159.

Solstad, T., Bjorgo, E., Koehler, C. J. Strozynski, M., Torgersen, K. M. Tasken, K., and Thiede, B. (2010). Quantitative proteome analysis of detergent-resistant membranes identifies the differential regulation of protein kinase $\mathrm{C}$ isoforms in apoptotic T cells. Proteomics 10, 2758 2768 .
Sommer, K., Guo, B., Pomerantz, J. L., Bandaranayake, A. D., MorenoGarcia, M. E., Ovechkina, Y. L., and Rawlings, D. J. (2005). Phosphorylation of the CARMA1 linker controls NF- $\kappa \mathrm{B}$ activation. Immunity 23 , 561-574.

Sun, Z., Arendt, C. W., Ellmeier, W., Schaeffer, E. M., Sunshine, M. J., Gandhi, L., Annes, J., Petrzilka, D., Kupfer, A., Schwartzberg, P. L., and Littman, D. R. (2000). PKC $\theta$ is required for TCR-induced NF- $\kappa \mathrm{B}$ activation in mature but not immature T lymphocytes. Nature 404, 402-407.

Szamel, M., Appel, A., Schwinzer, R., and Resch, K. (1998). Different protein kinase $\mathrm{C}$ isoenzymes regulate IL-2 receptor expression or IL-2 synthesis in human lymphocytes stimulated via the TCR. J. Immunol. 160, 2207-2214.

Takai, Y., Kishimoto, A., Inoue, M., and Nishizuka, Y. (1977). Studies on a cyclic nucleotideindependent protein kinase and its proenzyme in mammalian tissues. I. Purification and characterization of an active enzyme from bovine cerebellum. J. Biol. Chem. 252, 7603-7609.

Tan, S. L., Zhao, J., Bi, C., Chen, X. C., Hepburn, D. L., Wang, J., Sedgwick, J. D., Chintalacharuvu, S. R., and Na, S. (2006). Resistance to experimental autoimmune encephalomyelitis and impaired IL17 production in protein kinase $\mathrm{C}$ $\theta$-deficient mice. J. Immunol. 176, 2872-2879.

Thornton, A. M., Korty, P. E., Tran, D. Q., Wohlfert, E. A., Murray, P. E., Belkaid, Y., and Shevach, E. M. (2010). Expression of Helios, an Ikaros transcription factor family member, differentiates thymic-derived from peripherally induced Foxp3 $+\mathrm{T}$ regulatory cells. J. Immunol. 184, 34333441.

Thuille, N., Gruber, T., Bock, G., Leitges, M., and Baier, G. (2004). Protein kinase $\mathrm{C} \beta$ is dispensable for TCR-signaling. Mol. Immunol. 41, 385-390.

Thuille, N., Heit, I., Fresser, F., Krumbock, N., Bauer, B., Leuthaeusser, S., Dammeier, S., Graham, C., Copeland, T. D., Shaw, S., and Baier, G. (2005). Critical role of novel Thr-219 autophosphorylation for the cellular function of $\mathrm{PKC} \theta$ in T lymphocytes. EMBO J. 24, 38693880.

Trucy, M., Barbat, C., Fischer, A., and Mazerolles, F. (2006). CD4 ligation induces activation of protein 
kinase $\mathrm{C} \zeta$ and phosphoinositidedependent-protein kinase-1, two kinases required for down-regulation of LFA-1-mediated adhesion. Cell Immunol. 244, 33-42.

Trushin, S. A., Pennington, K. N., Carmona, E. M., Asin, S., Savoy, D. N., Billadeau, D. D., and Paya, C. V. (2003). Protein kinase $\mathrm{C} \alpha$ $(\mathrm{PKC} \alpha)$ acts upstream of $\mathrm{PKC} \theta$ to

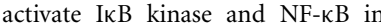
T lymphocytes. Mol. Cell. Biol. 23, 7068-7081.

Ueda, E., Ohno, S., Kuroki, T., Livneh, E., Yamada, K., Yamanishi, K., and Yasuno, H. (1996). The eta isoform of protein kinase C mediates transcriptional activation of the human transglutaminase 1 gene. J. Biol. Chem. 271, 97909794.

Volkov, Y., Long, A., and Kelleher, D. (1998). Inside the crawling $\mathrm{T}$ cell: leukocyte functionassociated antigen-1 cross-linking is associated with microtubule-directed translocation of protein kinase $\mathrm{C}$ isoenzymes $\beta(\mathrm{I})$ and $\delta$. J. Immunol. 161, 6487-6495.

Volkov, Y., Long, A., Mcgrath, S., Ni Eidhin, D., and Kelleher, D. (2001). Crucial importance of $\mathrm{PKC} \beta(\mathrm{I})$ in LFA-1-mediated locomotion of activated $\mathrm{T}$ cells. Nat. Immunol. 2, 508-514.

von Essen, M., Nielsen, M. W., Bonefeld, C. M., Boding, L., Larsen, J. M., Leitges, M., Baier, G., Odum, N., and Geisler, C. (2006). Protein kinase $\mathrm{C}(\mathrm{PKC}) \alpha$ and $\mathrm{PKC} \theta$ are the major PKC isotypes involved in TCR down-regulation. J. Immunol. 176, 7502-7510.

Watanabe, T., Ono, Y., Taniyama, Y., Hazama, K., Igarashi, K., Ogita, K., Kikkawa, U., and Nishizuka, Y. (1992). Cell division arrest induced by phorbol ester in $\mathrm{CHO}$ cells overexpressing protein kinase $\mathrm{C}-\delta$ subspecies. Proc Natl. Acad. Sci. U.S.A. 89, 1015910163.
Yang, D., Guo, J., Divieti, P., and Bringhurst, F. R. (2006). Parathyroid hormone activates PKC $\delta$ and regulates osteoblastic differentiation via a PLC-independent pathway. Bone 38, 485-496.

Zanin-Zhorov, A., Dustin, M. L., and Blazar, B. R. (2011). PKC $\theta$ function at the immunological synapse: prospects for therapeutic targeting. Trends Immunol. 32, 358-363.

Zhang, H. W., Yang, Y., Zhang, K., Qiang, L., Yang, L., Hu, Y., Wang, X. T., You, Q. D., and Guo, Q. L. (2008). Wogonin induced differentiation and G1 phase arrest of human U-937 leukemia cells via PKC $\delta$ phosphorylation. Eur. J. Pharmacol. 591, 7-12.

Zheng, Y., and Rudensky, A. Y. (2007). Foxp3 in control of the regulatory $\mathrm{T}$ cell lineage. Nat. Immunol. 8, 457-462.

Conflict of Interest Statement: The authors declare that the research was conducted in the absence of any commercial or financial relationships that could be construed as a potential conflict of interest.

Received: 12 April 2012; accepted: 08 July 2012; published online: 06 August 2012.

Citation: Pfeifhofer-Obermair C, Thuille $N$ and Baier $G$ (2012) Involvement of distinct $P K C$ gene products in $T$ cell functions. Front. Immun. 3:220. doi: 10.3389/fimmu.2012.00220

This article was submitted to Frontiers in $T$ Cell Biology, a specialty of Frontiers in Immunology.

Copyright (c) 2012 Pfeifhofer-Obermair, Thuille and Baier. This is an openaccess article distributed under the terms of the Creative Commons Attribution License, which permits use, distribution and reproduction in other forums, provided the original authors and source are credited and subject to any copyright notices concerning any third-party graphics etc. 